\title{
EU rules on corporate governance as means to promote sustainability?
}

\section{Izabella SCHIFFAUER}

\author{
WSB University in Wroclaw, Poland
}

\begin{abstract}
:
Aim: As part of the recent economic and financial crisis management in the EU new regulatory measures have been adopted which are of relevance for company law and corporate governance. Although the modalities of corporate governance are primarily determined by companies themselves, the establishment of basic national and EU level rules is required so that minimum standards are respected in the public interest. With regard to EU competences, they pertain to full implementation of and safeguarding proper functioning of the EU internal market (Article 3(3) TEU and Articles 26-27 TFEU). The purpose of this paper is to analyse EU regulatory measures in the field of corporate governance with a view to their potential positive impact on sustainable functioning of European companies, notably in the financial sector, and thus also the stability of the financial system at large.
\end{abstract}

Design / Research methods: The applied research methodology includes a combination of theoretical and analytical methods. The paper is based on a review of relevant literature and an analysis of EU regulatory measures pertaining to inter alia new capital requirements for financial institutions, shareholder's involvement and risk management.

Conclusions / findings: It is submitted that, at least in theoretical terms, the analysed regulatory measures have a potential of improving sustainability of single companies, thereby translating into improved reliability of the whole financial system, also by way of reducing the risk of moral hazard of failing banks counting on public money injections.

Implications/ Limitations of the research: The real impact on sustainability may, however, only be assessed once the dis-cussed EU measures have been fully implemented or, as the case may be, where and on condition that they are fully endorsed by the companies themselves. In that regard, the theoretical and analytical methods applied in this research prove insufficient to provide a fully satisfactory answer to the research question, with the real impact of the discussed measures on sustainability being a potentially interesting field of study on the basis of a sample of system relevant financial institutions in the years to come.

Key words: EU corporate governance framework; risk management; financial institutions, sustainability

JEL: G3, G01, K2, H12

Correspondence address: Izabella Schiffauer, WSB University in Wrocłąw, u. Fabryczna 29-31, 53-609 Wrocław, Poland. E-mail: Izabella.schiffauer.wsb.wroclaw.pl

Received: 21-09-2017, Accepted: 28-12-2017

doi: http://dx.doi.org/10.29015/cerem.567 


\section{Introduction}

The EU company law has been devised with a view to establishing and safeguarding common commercial and competition rules for the functioning of the internal market (Article 3(1) of the Treaty on the Functioning of the European Union, TFEU). As an integral part of the internal market, harmonised EU company law facilitates freedom of establishment of companies within the Union and fosters legal certainty for their activities. At the same time, foundations for best corporate governance practices are provided for within the EU framework, the aim of which is to enhance companies' competitiveness and sustainability. In its Green Paper of 5 April 2011 (EC 2011: 2), the European Commission points to corporate governance and corporate social responsibility (CSR) as key elements in building people's trust in the single market and contributing to the competitiveness of European business, since well-run and sustainable companies are indispensable in order to achieve the ambitious growth targets set by 'Agenda 2020' (see EC 2010). It is noteworthy that the EU economic and monetary policy is not limited to the pursuit of sound and sustainable public finances and price stability (cf. Allemand, Martucci 2012: 47). It is also oriented towards improving the efficiency of Member States economies with a view to enhancing the favorable environment for growth, high employment and social cohesion (CEU 1998: point 7). With respect to creating favorable environment for growth, emphasis is placed inter alia on promoting entrepreneurship and facilitating access to markets and financing, notably for small and medium-sized enterprises (CEU 1998: point 8).

The experience of the most recent financial and sovereign debt crises clearly showed that efficient and responsible corporate governance is of vital importance not only for the sound operation of individual enterprises, but also the stability of financial markets and the economy at large. In particular the developments in the banking sector proved that a self-regulatory market approach based exclusively on non-binding recommendations does not provide for a sufficient guarantee of sound corporate governance. In the light of the above, good corporate governance should not be construed exclusively as an end in itself, but a means to support economic efficiency, sustainable growth and financial stability (G20/OECD 2015). 
Consequently, while the modalities of corporate governance are first and foremost the responsibility of companies themselves, the establishment of fundamental national and EU level rules is justified so as to ensure that minimum standards are respected in the public interest. Regarding EU competences in this area, they pertain to full implementation and safeguarding of proper functioning of the EU internal market (Article 3(3) of the Treaty on European Union (TEU) and Articles 26-27 TFEU).

The purpose of this contribution is to analyse EU legal provisions pertaining to corporate governance with a view to their potential influence on sustainable operation of companies. First the concept and scope of EU corporate governance framework is explained, followed by a diachronic analysis of the development of relevant EU company law and corporate governance framework. The EU regulatory activity in the field shortly prior as well as in response to the most recent financial and sovereign debt crises is most relevant from the perspective of sustainability. The applied research methodology includes a combination of theoretical and analytical methods.

\section{The concept, scope and legal basis of EU corporate governance framework}

For the sake of clarity, under the EU corporate governance framework we should understand both legislation in areas such as corporate governance statements, transparency of listed companies, shareholders' rights and takeover bids as well as 'soft law', i.e. non-binding recommendations concerning e.g. the role and the remuneration of companies' directors (EU 2012: 2, note 10). As to corporate governance, it consists in a set of relationships between a company's management, its board, its shareholders and other stakeholders (OECD 2004: 11). In simple terms, it determines the manner in which companies are managed and controlled, thus constituting an important criterion for their existence and competitiveness (cf. Vogel 2007: 217). Corporate governance should therefore provide for an arrangement whereby the objectives of the company are set, and the means of attaining them as well as monitoring performance to that end are determined. 
The scope of EU company law, including corporate governance, covers the protection of interests of shareholders and other parties, the constitution and maintenance of public limited-liability companies' capital, branches disclosure, mergers and divisions, minimum rules for single-member private limited-liability companies and shareholders' rights as well as legal forms of undertakings such as the European Company (SE), the European Economic Interest Grouping (EEIG) and the European Cooperative Society (SCE) (EU 2012: 3, note 17). It should be noted here that while EU company law in principle may concern all EU public companies with limited liability, EU corporate governance rules apply exclusively to companies listed on a stock exchange.

European businesses and national legislators operate within the framework of primary EU law, i.e. the Treaty provisions on the right of establishment (Article 49 TFEU) and the free movement of capital (Article 63 TFEU), secondary EU law measures regulating companies as well as relevant soft law initiatives. Pursuant to Article $50(2)(\mathrm{g})$, the Union has competence to act in the area of corporate governance, notably by way of coordination measures with regard to the protection of interests of companies' members and other stakeholders (e.g. creditors), so as to ensure that such protection is equivalent throughout the EU.

\section{The elaboration of the EU corporate governance framework - a diachronic perspective}

The EU framework pertaining to company law and corporate governance has been steadily elaborated over years (for a comprehensive account, see e.g. Edwards 1999; Vossestein 2010: 29ff). As early as in 1968, the First Company Law Directive (CEC 1968) regulating disclosure, the power of representation of company organs and the nullity of companies with limited liability was adopted, the adoption of the Twelfth Company Law Directive on single-member private companies (CEC 1989b: 40-42) took place in 1989. In the period between the above specified years, nine other important Directives and one Regulation on European Economic Interests Grouping (EEIGs) (CEU 1985: 1-9) were enacted which laid down inter alia rules of formation of companies with limited liability, maintenance and alteration of capital, 
annual accounts and statutory audits, mergers and divisions. The Draft Fifth Company Law Directive concerning the management structure of companies, and thus one of the most important directives for corporate governance, was never adopted by the Council since some Member States opposed it to come into law. It intended to grant employees the right to vote for a supervisory board in the obligatory two-tiered boards of directors. Even though this draft Directive had undergone three major revisions, including the abandonment of the two-tier board system (see further e.g. Murphy 1985), the compromise on the text was not achieved.

As regards specifically banking law, first Community legislative measure was the Directive 73/183/EEC (CEC 1973: 1-10), the objective of which was to enable free establishment of credit institutions within the Union. The harmonisation in the field of substantive banking law was effected by Directive 77/780 of 1977 (First Banking Directive) (CEU 1977: 30-37), thus creating the foundations for a single market for banking. In 1993 Directive 89/646/EEC (Second Banking Directive) (CEC 1989a: 1-13) was adopted whereby a credit institution authorised in one Member State is entitled to provide services within the whole EU, unimpeded of additional requirements of authorisation in other Member States (see Söderström 2015: 115). A major codification activity was carried out in 2000, whereby seven Banking Directives and their amending Directives were replaced by one single Banking Directive 2000/12/EC (EU 2000: 1-59).

The decade following the enactment of the Twelfth Company Law Directive was marked by a notable loss of dynamism in the EU (at that time Community) law harmonisation process (Wouters 2000: 257). Indeed the enactment of the Thirteenth Company Law Directive (EU 2004: 12-23) aimed at achieving greater legal certainty with regard to takeover bids was delayed until 2004 (since in the proceedings for the adoption of this directive the European Parliament for the first time rejected in plenary a compromise that was proposed by the conciliation committee), with the EU regulatory activity in the field subsequently regaining momentum in the context of the Union's crisis management (see Section 4 infra). This pertains in particular to regulatory activity in areas of financial stability, risk management as well as consumer and investor protection, aimed at preventing all 
types of financial turbulence in future (Söderström 2015: 115). Alongside the increase in the volume, strictness (i.e. possibility to impose sanctions for noncompliance) and pace of regulatory measures, there is also a notable shift in the instrument that is applied to this end, namely: numerous directives are being replaced or complemented by directly applicable EU regulations, with banking sector being particularly targeted through this regulatory agenda ${ }^{1}$ (Söderström 2015 : $115)$.

\subsection{Relevant case law}

The Court of Justice of the EU (the ECJ) has brought a major contribution to the elaboration of the Community, and subsequently Union rules pertaining to the freedom of establishment and operation of European businesses by way of its interpretation of the treaty provisions, with the Court's jurisprudence being clearly supportive of unrestricted exercise of economic freedoms by the EU nationals. To give just a few examples, in Case 270/83 Commission v France ${ }^{2}$ the ECJ ruled that the right of establishment (Article 49 TFEU, ex Article 52 EEC Treaty) embraces the right for business undertakings formed in accordance with the law of a Member State to take up and pursue their business activities in another Member State through an agency, branch or subsidiary and under the conditions laid down by the law of the state where they have their registered office and principal location of business activity (see further Edwards 1999: 344-347 and 349-350). Furthermore, in Case C212/97 Centros Ltd v Erhvervs the ECJ ruled that it is in breach of Articles 52 and 58 of the EEC Treaty refusing to register a branch of a company formed in accordance with the law of another Member State in which it has its registered office (in this particular case in the UK) but in which it conducts no business activity, where the branch was intended to enable the company in question to carry on its entire business in the State in which that branch was to be created (here Denmark), while avoiding the need to form a company there, thereby evading application of the

\footnotetext{
${ }^{1}$ E.g. the so called "CRD III" package on capital requirements and remuneration policies (two directives) has been overhauled by a Capital Requirements Directive (CRD IV) and a Regulation on prudential requirements for credit institutions and investment firms (CRR), with the latter instrument having the advantage of taking immediate effect in all Member States in the same way as a national instrument. For further account, see Section 4 below.

${ }^{2}$ Case C-270/83 [1983] ECR 273, notably para 13.
} 
rules governing the formation of companies which, in that State, are more restrictive as regards the minimum share capital. At the same time the Court held that such interpretation does not prevent the authorities of the Member State concerned from adopting any appropriate measure aimed to prevent or penalise fraud or evasion on the part of the company members regarding their obligations towards private or public creditors established in the territory of the Member State concerned. The ECJ recalled in this context its earlier case-law according to which national measures which hinder or make less attractive the exercise of fundamental freedoms safeguarded under the Treaties must meet four conditions, namely: i) be applied in a non-discriminatory manner; ii) be justified by imperative requirements in the general interest; iii) be suitable for securing the attainment of the objective which they pursue; and finally, iv) not go beyond what is necessary in order to attain it (Case C19/92 Kraus v Land Baden-Württemberg [1993] ECR I-1663, paragraph 32, and Case C-55/94 Gebhard v Consiglio dell'Ordine degli Avvocati e Procuratori di Milano [1995] ECR I-4165, paragraph 37). In the view of the Court, the said conditions are not fulfilled in the Centros case and the creditors not only are on notice that company is governed by laws different from those in Denmark, but may also seek protection under certain rules of Community law, e.g. Fourth Council Directive 78/660/EEC of 25 July 1978 based on Article 54(3)(g) of the Treaty on the annual accounts of certain types of companies (CEC 1978: 11-31), and the Eleventh Council Directive 89/666/EEC of 21 December 1989 concerning disclosure requirements in respect of branches opened in a Member State by certain types of company governed by the law of another State (CEU 1989: 36-39). ${ }^{3}$

The ECJ also opposed any limitation of the exercise of fundamental economic freedoms in Case 208/00 Überseering BV v Nordic Construction Company Baumanagement $\mathrm{GmbH}$ (NCC) where it held that Articles 43 and 48 EC Treaty (current Articles 49 and 54 TFEU respectively) preclude the non-recognition by the host Member State of the company's legal capacity and its capacity to be a party to legal proceedings on grounds that the company has not been reincorporated in the host state to which it actually transferred its centre of administration. The Court holds that establishing a difference in treatment between companies is forbidden

\footnotetext{
${ }^{3}$ For the ECJ's judgment, see in particular ECJ (1999), points 34-36 and 38-39.
} 
unless "it pursues a legitimate objective compatible with the Treaty and is justified by imperative reasons in the public interest. It is further necessary, in such a case, that its application must be appropriate to ensuring the attainment of the objective thus pursued and must not go beyond what is necessary to attain it."

Noteworthy is also Case C-411/03 SEVIC Systems AG concerning cross-border merger operations where the ECJ construed them as particular methods of exercise of the freedom of establishment important for the proper functioning of the internal market, and therefore amongst those economic activities in respect of which Member States are required to comply with the freedom of establishment laid down in Article 43 EC Treaty. As a matter of principle, providing for by law for a difference in treatment between companies according to the internal or cross-border nature of the merger is in the view of the Court contrary to the right of establishment, and thus may be permitted only if a legitimate objective compatible with the Treaty is pursued, which is justified by imperative reasons in the public interest. These could be e.g. protection of the interests of creditors, minority shareholders and employees, as well as preservation of the effectiveness of fiscal supervision and the fairness of commercial transactions. On those grounds the ECJ held that it is an unjustified restriction of the freedom of establishment when the law of a Member State allows, as long as certain conditions are met, for registration in the national commercial register of a merger by dissolution without liquidation of a company and transfer of its entire assets to another company, provided that the two companies effecting the merger are both established in its territory, but refuses such registration in general in the case when one of the two companies is established in another Member State. ${ }^{5}$ On the other hand, in Case C-210/06 Cartesio the ECJ stated that it is not contrary to Articles $43 \mathrm{EC}$ and $48 \mathrm{EC}$ when the law of a Member State under which a company is incorporated prohibits the transfer of that company seat to another Member State where its status as a company governed by the law of the Member State of incorporation is to be retained. ${ }^{6}$

\footnotetext{
${ }^{4}$ Case C-208/00 [2002] ECR I-9919.

${ }^{5}$ Case C-411/03 [2005] ECR I-10805, in particular paras 19 and 22-23, 28 and 31.

${ }^{6}$ Case C-210/06 [2008] ECR I-09641.
} 


\subsection{Harmonisation activity of EU company law shortly prior to the crisis}

A most comprehensive pre-crisis review in this policy area was launched by the European Commission through the 2003 Action Plan on Modernising Company Law and Enhancing Corporate Governance in the European Union (henceforth the 2003 Action Plan) (EU 2003). The need for the European regulatory framework for company law and corporate governance to be modernised was recognised inter alia for the following reasons:

- the growing trend of European companies to operate cross-border in the Internal Market, which inevitably creates the need for common European company law mechanisms so as to facilitate freedom of establishment (Article 49 TFEU) and cross-border restructuring;

- the continuing integration of European capital markets, in which context both issuers and investors should have an opportunity to intensify their activity on other EU capital markets and to have confidence that the companies they invest in have equivalent corporate governance frameworks;

- the rapid development of new information and communication technologies, the benefits of which development should be properly exploited;

- the (then) forthcoming enlargement of the EU to 10 new Member States which called for revisiting the EU corporate governance acquis (the 2003 Action Plan, point 1.2).

The 2003 Action Plan put forth a set of legislative and non-legislative proposals relating inter alia to corporate governance, corporate restructuring and mobility, capital maintenance and alteration and transparency. The proposals for action were organised according to the short-term (2003-2005), medium-term (2006-2008) and long-term (2009 onwards) timescales and were allocated an appropriate type of regulatory instrument to be applied so as to achieve the desired outcomes. The main objectives of the Action Plan were to strengthen shareholders' rights and protection for employees, creditors and the other parties which companies deal with, while adapting company law and corporate governance rules appropriately for different categories of company. ${ }^{7}$ Amongst successful legislative initiatives count inter alia

\footnotetext{
${ }^{7}$ On the adaptation of company law to different categories of company in the national context, see e.g. De Jong (2016).
} 
the amendment of the Accounting Directive (CEC 1978), ${ }^{8}$ or more precisely a consolidation of existing Directives on annual accounts of companies with limited liability with the aim of coordinating Member States' provisions concerning the presentation and content of annual accounts and annual reports, the valuation methods used and their publication regarding all companies with limited liability (EU 2006a: 87-107, 2006b: 1-7, 2009: 42-44). Strict rules were also operated in respect of publication of documents and system of auditing, with only SMEs being subject to less restrictive rules. Apart from Accounting Directive, rules on an annual corporate governance statement have also been introduced by a Directive 2007/36/EC on the exercise of shareholders' rights (EU 2007: 17-24) and the Tenth Company Law Directive (2005/56/EC) on Cross-border mergers (EU 2005: 1-9). The latter Directive constituted a relevant step forward in respect of cross-border mobility ${ }^{9}$ in the EU. Still, the current EU framework admits the co-existence of different national company law which legally excludes that companies transfer their seat across borders (the rules contained in the Statutes for the European Company (SE), for the European Cooperative Society (SCE) and for the European Economic Interest Grouping (EEIG) are exception in that regard) while at the same time preserving the company's legal personality. That is, unless a registered office transfer is allowed under applicable national law, companies are forced to first wind up and subsequently re-incorporate. In the same vein, while Directive 82/891/EEC (CEu 1982: 47-54) has harmonised company divisions at national level, the EU legislation allowing for cross-border divisions is missing. Interestingly, a public consultation conducted amongst stakeholders by the European Commission in 2012 revealed considerable support for establishing EU rules both regarding cross-border transfer of seat (373 out of a total of 496 replies) and cross-border divisions (318 out of a total of 496 replies $)^{10}$, albeit any legislation in that respect implies concrete risks and possibly moral hazard, e.g. in terms of tax avoidance or insolvency fraud, respectively.

8 For an exhaustive list of amending acts, see http://eur-lex.europa.eu/legalcontent/PL/TXT/?uri=URISERV\%3Al26009 [17.02.2018].

${ }^{9}$ It would merit further investigation to clarify whether in this case the prevailing aspect is the mobility of companies or the mobility of capital.

10 Cf. the feedback statement of 17 July 2012 and submitted responses at: http://ec.europa.eu/internal_market/consultations/2012/company_law_en.htm [12.01.2017]. 
It is noteworthy that the EU corporate governance framework takes stock of international and national soft law codes without having elaborated its own "European" corporate governance code. In the view of the European Commission, such an EU-specific code would not offer a significant added value but constitute an additional layer between international principles and national codes (EC 2003). Therefore, the role of the EU is limited to safeguarding adequate coordination of the latter while providing for the most essential rules within a common approach.

Throughout the Union national corporate governance codes are applied on a "comply or explain" basis, i.e. companies are allowed to depart from selected rules or recommendations of the code applicable in their domestic jurisdictions or, alternatively, the code which the company may have voluntarily decided to apply, albeit they must explain the grounds for such a decision. The comply or explain principle was for the first time explicitly introduced in the EU law in 2006 through Directive 2006/46/EC amending Directive 78/660/EEC (EU 2006a: 1-7) ${ }^{11}$, namely by way of inserting Article 46a which stipulates that a corporate governance statement in a company's annual report shall contain, "to the extent to which a company, in accordance with national law, departs from a corporate governance code (...), an explanation by the company as to which parts of the corporate governance code it departs from and the reasons for doing so." On the one hand, this non-mandatory system leaves businesses the necessary flexibility to adapt to changing legal, economic, and market realities depending on their individual situation and needs. On the other hand, the quality of corporate governance reports in terms of explanations provided by numerous listed companies for deviations from corporate governance codes is insufficient. This was confirmed by the Study on Monitoring and Enforcement Practices in Corporate Governance (EC 2009) conducted by the Risk Metrics Group for a sample of 270 listed companies from 18 Member States. According to the study, even though a large majority of market actors and regulators consider the comply-or-explain approach as an appropriate and efficient regulatory tool, there is a wide consensus that the mechanism does not function properly. The problem of low disclosure quality of company statements is raised in particular by investors who need dependable information to take their

\footnotetext{
${ }^{11}$ See in this regard amendments to Directive 78/660/EEC, namely the inserted Article 46a.
} 
investment decisions and assess the value of a company (EU 2012: 6, note 6). Shortcomings in that regard limit the system's usefulness and viability. In the light of the fact that shortcomings in corporate governance practices have been highlighted as one of the causes of the recent financial crisis ${ }^{12}$, new EU-level regulatory-corrective action has been undertaken with a view to improving the $\mathrm{EU}$ corporate governance framework.

\section{EU regulatory activity in response to the crises: Towards more sustainable corporate environment?}

Since its endorsement in the Treaty of Amsterdam, sustainable development has constituted an overarching objective of EU policies, in view of which economic, social and environmental dimensions should be concomitantly handled. Article 3(3) TEU stipulates that the Union "shall work for the sustainable development of Europe based on balanced economic growth and price stability, a highly competitive social market economy, aiming at full employment and social progress, and a high level of protection and improvement of the quality of the environment." Thus, reconciling economic efficiency, social inclusion and environmental responsibility is the essence of sustainable development (see EC 2016), which requires notably that a pursuit of economic growth does not compromise the societal and environmental components. However, since the interplay of the said elements is marked by inherent conflict of interest, the implementation of sustainability principle has continued to pose a real challenge.

At the same time sustainable development is very much dependent on the stability and reliability of banks which continue to play a major role in financing economic activity and growth. Therefore the recent financial and sovereign debt crises have provided EU decision-makers a new impulse to reconsider the conditions required for a more "sustainable" financial sector. Most relevant regulatory amendments that were introduced so as to prevent future turbulence of that kind concerned the following areas:

12 See e.g. the International Corporate Governance Network's Second statement on the Global Financial Crisis of 23 March 2009, as cited in EU (2009: 13, note 3). 
- $\quad$ risk management

- shareholders' engagement.

Board practices remain subject to comply or explain mechanism, where enhanced transparency is the only means to compensate the absence of enforceable rules. By way of example, the European Commission advocates amongst others increased transparency with regard to companies' board diversity policy (EU 2012: 5), whereby the Board's capacity to effectively and constructively challenge the management's decisions may arguably be increased.

As has already been emphasized, the EU legislator focused in particular on inappropriate risk management and excessive short-termism in financial institutions, given the direct impact the said institutions may have on systemic risk and the economy as a whole. In order to create sound remuneration policies that do not encourage or reward excessive risk-taking, the so called CRD III package (EU 2010: 3-35) was adopted in 2010. It was subsequently amended by the Capital Requirements Directive (CRD IV) (EU 2013a: 338) and Regulation on prudential requirements for credit institutions and investment firms (CRR) (EU 2013b: 1-337) which operated more restrictive requirements for:

- capital, liquidity and leverage standards, as agreed in the Basel Committee on Banking Supervision ("Basel III");

- the relationship between the variable (or bonus) component of remuneration and the fixed component (or salary), with the new rules being applicable to credit institutions and investment firms, both listed and non-listed.

The intended added value of CRR as a legislative instrument (directly applicable regulation) is that it establishes a single set of harmonised prudential rules (referred to as a "single rule book") which banks throughout the EU must respect.

Remarkably, whilst corporate governance in institutions outside the financial sector gave not so much concern as that of the financial sector, also these institutions have been affected by a lack of shareholder interest in holding management accountable for their decisions and actions, which appears to be linked to limited shareholders' commitment demonstrated in particular by the fact that many shareholders hold their shares for only a short period of time. In response to that development, in April 2014, the European Commission published a Proposal for a 
Directive as regards the encouragement of long-term shareholder engagement (EU 2014d). While remaining without prejudice to the core principle of "comply or explain" approach in the EU corporate governance framework allowing Member States and companies to fine-tune to their specific corporate culture, traditions and needs, in view of the ever more intense cross-border activity, the proposal embraced a number of elements of corporate governance (e.g. shareholder identification, the transparency and engagement of institutional investors and board remuneration) so as to ensure a harmonised approach across the Union. In concrete terms, the by now adopted Directive (EU) 2017/828 (EU 2017: 1-25) is aimed at safeguarding that shareholders have a vote on the remuneration policy and report, as well as related party transactions. The said amendment of the Directive 2007/36/EC is binding as from June 2017, with Member States being obliged to transpose this Directive into national law by 10 June 2019 .

In the table below selected measures undertaken by the EU institutions with a view to safeguarding sustainable operation of institutions are briefly outlined. It should be emphasized here that for the purposes of this paper the term sustainability should not be construed as commonly applied in the context of "sustainable" or "ethical" banking, but more broadly, conveying concepts such as "durable" or "lasting". 

Table 1. Contents and enhanced sustainability potential of selected EU
regulatory measures relating to company law and corporate governance

\begin{tabular}{|c|c|c|}
\hline $\begin{array}{l}\text { Legal act(s) or } \\
\text { soft law measure }\end{array}$ & Most relevant amendment(s) & $\begin{array}{l}\text { Enhanced Sustainability } \\
\text { (Yes/ No - and why) }\end{array}$ \\
\hline $\begin{array}{l}\text { "CRD-IV } \\
\text { Package": } \\
\text { - Capital } \\
\text { Requirements } \\
\text { Directive } \\
\text { (Directive } \\
\text { 2013/36/EU) (EU } \\
\text { 2013a) and } \\
\\
\text { - Capital } \\
\text { Requirements } \\
\text { Regulation } \\
\text { (Regulation (EU) } \\
\text { No 575/2013) (EU } \\
\text { 2013b) }\end{array}$ & $\begin{array}{l}\text { New prudential requirements for financial } \\
\text { institutions: } \\
\text { stricter rules on the amount and quality of } \\
\text { capital; } \\
\text { stricter rules on the amount of short- and long- } \\
\text { term liquidity } \\
\text { leverage backstop (a mechanism limiting the } \\
\text { growth of the total balance sheet as compared to } \\
\text { available funds) } \\
\text { II. More restrictive requirements for the } \\
\text { relationship between the variable (or bonus) } \\
\text { component of remuneration and the fixed } \\
\text { component (or salary), i.e. , the variable } \\
\text { component of the total remuneration shall not } \\
\text { exceed } 100 \% \text { of the fixed component of the total } \\
\text { remuneration takers (only exceptionally and } \\
\text { subject to shareholder agreement the ratio may } \\
\text { amount to } 200 \% \text { ). } \\
\text { III. Obligation for institutions that are } \\
\text { significant in terms of their size, internal } \\
\text { organisation and the nature, scope and } \\
\text { complexity of their activities to establish a risk } \\
\text { committee composed of members of the } \\
\text { management body } \\
\text { who do not perform any executive function in the } \\
\text { institution concerned (Art. } 76 \text { para } 3 \text { of the } \\
\text { Directive). } \\
\text { Pursuant to Art. } 74 \text { para } 1 \text {, institutions shall also } \\
\text { have "robust governance arrangements" } \\
\text { consisting inter alia in well-defined, transparent } \\
\text { and consistent lines of responsibility, effective } \\
\text { processes to identify, manage, monitor and report } \\
\text { the risks they are or might be exposed to, } \\
\text { adequate internal control mechanisms, and } \\
\text { remuneration policies and practices that are } \\
\text { consistent with and promote sound and effective } \\
\text { risk management. }\end{array}$ & $\begin{array}{l}\text { Yes, in terms of improved liquidity } \\
\text { capacity of financial institutions aimed at } \\
\text { strengthening the EU banking sector's } \\
\text { resilience and its capacity to absorb } \\
\text { economic shocks; apart from capital as } \\
\text { prudential reference bank supervision } \\
\text { will also look into liquidity and leverage } \\
\text { standards, thus covering the whole } \\
\text { balance sheet of banks. } \\
\text { Yes, due to limiting financial incentive } \\
\text { stirring risk appetite and risk-taking } \\
\text { activity. }\end{array}$ \\
\hline
\end{tabular}

Source: Author's own elaboration.

${ }^{13}$ Leverage backstop is a new tool for the international framework and will therefore be introduced as a binding requirement in national jurisdictions only after enough data and experience have been gathered to determine an effective leverage ratio, see: EC (2013b). 
Table 1. Cont.

\begin{tabular}{|c|c|c|}
\hline $\begin{array}{l}\text { Legal act(s) or soft } \\
\text { law measure }\end{array}$ & Most relevant amendment(s) & $\begin{array}{l}\text { Enhanced Sustainability } \\
\text { (Yes/ No - and why) }\end{array}$ \\
\hline $\begin{array}{l}\text { Commission } \\
\text { Delegated } \\
\text { Regulation (EU) No } \\
527 / 2014 \text { (EU } \\
2014 a)\end{array}$ & $\begin{array}{l}\text { Specification of the classes of instruments } \\
\text { which are intended to: } \\
\text { - reflect the credit quality of an } \\
\text { institution; } \\
\text { - be appropriate for the purposes of } \\
\text { variable remuneration. }\end{array}$ & $\begin{array}{l}\text { Potentially yes, as variable remuneration } \\
\text { awarded in instruments may promote sound } \\
\text { and effective risk management, while not } \\
\text { encouraging risk-taking which exceeds the } \\
\text { level of tolerated risk of the institution. }\end{array}$ \\
\hline $\begin{array}{l}\text { - Council Regulation } \\
\text { (EU) No 1024/2013 } \\
\text { (prudential } \\
\text { supervision of credit } \\
\text { institutions) (EU } \\
\text { 2013c) } \\
\text { - Bank Recovery and } \\
\text { Resolution Directive } \\
\text { (BRRD, Directive } \\
\text { 2014/59/EU) (EU } \\
\text { 2014b) }\end{array}$ & $\begin{array}{l}\text { Introduction of an EU-level: } \\
\text { - banking supervision (conferred to the } \\
\text { ECB) by means of the Single Supervisory } \\
\text { Mechanism (SSM) } \\
\text { - banking resolution system (Single } \\
\text { Resolution Mechanism (SRM)) with a } \\
\text { Single Resolution Fund (SRF) to be built } \\
\text { up progressively (a period of } 8 \text { years) by } \\
\text { 'ex-ante' contributions from the banking } \\
\text { industry. BRRD made also mandatory } \\
\text { rules on bank "bail-ins", i.e. a mechanism } \\
\text { for effecting the exercise of the write- } \\
\text { down and conversion powers by } \\
\text { resolution authorities in relation to } \\
\text { liabilities of an institution which is failing } \\
\text { or likely to fail. The modalities of } \\
\text { application of the bail-in tool are laid } \\
\text { down in Article } 27 \text { of the Regulation (EU) } \\
806 / 2014 \text { (EU } 2014 \mathrm{c}: 1-90 \text { ). }\end{array}$ & $\begin{array}{l}\text { Yes, insofar as continuity of critical functions } \\
\text { and protection of depositors, investors, client } \\
\text { funds and assets is safeguarded. In addition, } \\
\text { there is a potential of added value in } \\
\text { macroeconomic terms, where the mechanism } \\
\text { helps avoid adverse effects on financial } \\
\text { stability (including protection of public funds), } \\
\text { notably by preventing contagion and by } \\
\text { maintaining market discipline (minimising } \\
\text { reliance on extraordinary public financial } \\
\text { support). At the same time, SRF allows for } \\
\text { risk mitigation through risk-sharing. }\end{array}$ \\
\hline
\end{tabular}

Source: Author's own elaboration. 
Table 1. Cont.

\begin{tabular}{|c|c|c|}
\hline $\begin{array}{l}\text { Directive (EU) } \\
2017 / 828 \\
\text { (encouragement of } \\
\text { long-term } \\
\text { shareholder } \\
\text { engagement) (EU } \\
2017 \text { ) }\end{array}$ & $\begin{array}{l}\text { II. Increased transparency in terms of: } \\
\text { 1. identification of shareholders; } \\
\text { 2. transmission of information facilitating } \\
\text { the exercise of shareholders' rights; } \\
\text { 3. requirement of disclosure of } \\
\text { - investment strategy by institutional } \\
\text { investors and asset managers; } \\
\text { - methodology and modalities of services } \\
\text { provided by proxy advisors } \\
\text { or alternatively of a reasoned explanation } \\
\text { of the grounds for non-compliance (Art. } \\
3 \mathrm{~g} \text { ). }\end{array}$ & $\begin{array}{l}\text { Potentially yes, since the vote of shareholders } \\
\text { shall be binding, albeit the major effect of the } \\
\text { new regulation needs to be achieved first, } \\
\text { namely: long-term engagement of } \\
\text { shareholders whose interests will rest more in } \\
\text { sustainability of their investee company rather } \\
\text { than short-term gain. Given that the impact of } \\
\text { the new provisions as initially proposed by the } \\
\text { Commission }{ }^{14} \text { has been weakened in the } \\
\text { legislative process (see paragraph below) as } \\
\text { well as lacking incentives for shareholders to } \\
\text { compromise risk appetite for the sake of } \\
\text { sustainability, the qualitative change is only } \\
\text { limited. } \\
\text { Potentially yes (e.g. through better managing } \\
\text { actual or potential conflict of interest), but its } \\
\text { impact is considerably reduced by the } \\
\text { possibility to publicly disclose only the } \\
\text { explanation stating reasons for non- } \\
\text { compliance. In the light of the experiences } \\
\text { made to date with the functioning of the } \\
\text { "comply or explain" principle, notably in } \\
\text { terms of the quality of reporting, the real } \\
\text { impact on transparency and thus also } \\
\text { sustainability will very likely be rather } \\
\text { modest, unless external impulses or pressure is } \\
\text { exerted in the institutions. }\end{array}$ \\
\hline
\end{tabular}

Source: Author's own elaboration.

\section{Concluding remarks}

The above analysis allows for a conclusion that whilst in the initial phase of European integration process the EU rules on corporate governance were mostly concentrated on facilitating freedom of economic activity within the Internal Market, in the course of time the objective of sustainable development has been gaining more recognition, with a "climax" being achieved in the years following the outbreak of the financial and economic crises in 2008. The Commission's legislative agenda pursued in its 2012 Action Plan with a view to modernising the EU company law and corporate governance regulatory framework in respect of supporting companies' growth and their competitiveness, engaging shareholders in corporate

\footnotetext{
${ }^{14}$ See supra note 42 .
} 
governance, enhancing transparency, as well as rendering the framework itself simpler and thus more user-friendly (see EU 2012: 4) is still to some extent "in progress". A question which this paper attempts to address is whether those highly ambitious objectives, if not accomplished yet, have a potential of contributing to a fairer Internal Market in general and improved business environment in terms of sustainability.

The aspect which is easiest to address pertains to simplification of the EU corporate governance framework. While not challenging good reasons for the replacement of two or more instruments by way of a single new act, the overall increase of regulatory measures, including Commission delegated and implementing acts, seems to more than outweigh the reduced complexity of the revised law. A reason for the continuing increase of the regulatory density may be that the scope of regulated areas tends also to be extended. It remains questionable, however, whether the search of regulatory perfectionism on the side of the legislator is really improving the law. On the other hand, the observable regulatory activity trend may be interpreted as aimed at counter-acting excessive deregulation which demonstrated its drawbacks in the context of the financial and sovereign debt crises. The constitutional shortcomings of the EU macroeconomic governance are widely recognized in literature (see e.g. Adamski 2013; Touri, Touri 2014). According to the conventional wisdom, liberalisation provides for entrepreneurship spirit and growth, while leaving the corrective function to the self-regulatory forces of the market. This stance is broadly criticised in more recent literature (see e.g. Picketty 2013; Krugman 2012: 96 ff) and put under stress when particularities of economic systems are given more attention to, with the outcomes of financial liberalisation being by and large dependent on the general level of development, the condition of domestic financial markets, and the quality of institutions (see Broner and Ventura 2010). This is why a reverse trend may be observed in literature construing financial liberalization as an explanatory variable of banking crisis. A more balanced view is advanced by Majerbi and Rachdi (2014) who argue that, whilst the immediate effect of liberalisation translates into an increased risk of crisis, at a certain critical point liberalisation starts to have a negative relationship with the probability of crisis occurrence, with the said turning point at which further liberalization starts reducing 
the likelihood of crisis appearing to vary not only depending on the type of economy (advanced vs. emerging/developing), but also its level of financial liberalisation (Majerbi, Rachdi 2014: 325). The stance that is advanced in this paper is that while the embedded liberal bargain of the EU internal market (Ashiagbor 2013) presupposes financial liberalisation, it should nevertheless be offset by a stricter supervision and corrective regulatory activity where need there is. A trend in this direction is clearly observable in the context of EU crisis management, including in the area of corporate governance.

It is arguable that the discussed EU regulatory measures have a potential of improving sustainability of single companies, were it through stricter prudential requirements for credit institutions and investment firms, enhanced long-term involvement of shareholders with their investee companies or remuneration policies that do not encourage or reward excessive risk-taking. The improved reliability of the whole financial sector is also achieved by the "bail-in" mechanism, which evidently reduces the risk of moral hazard of failing banks counting on public money injections, thus contributing to a more stable economic and financial system as a whole. However, despite the tangible added value of these measures, their real impact on sustainability of single companies may only be assessed once they have been fully implemented or, as the case may be, where and on condition that they are effectively endorsed by the companies themselves. It is not exaggerated to say that such endorsement may only take place if the companies self-reflexively recognize the need thereof. In that regard, the theoretical and analytical methods applied in this research prove insufficient to provide an entirely satisfactory answer to the research question, with the real impact of the discussed measures on sustainability being a potentially interesting field of study on the basis of a sample of system relevant financial institutions in the years to come. 


\section{References}

Adamski D. (2013), Europe's (misguided) constitution of economic prosperity, „Common Market Law Review", vol. 50 no. 1, pp. 47-86.

Allemand F., Martucci F. (2012), La nouvelle gouvernance économique européenne - partie 1, „Cahiers de droit européen”, vol. 48 no. 1, pp. 17-99.

Ashiagbor D. (2013), Unravelling the embedded liberal bargain. Labour and social welfare law in the context of EU market integration, „European Law Journal”, vol. 19 no. 3, pp. 303-324.

Broner F.A., Ventura J. (2010), Rethinking the effects of financial liberalization, NBER Working Paper No. 16640, http://www.nber.org/papers/w16640.pdf [17.02.2018].

De Jong B.J. (2016), The distinction between public and private companies and its relevance for company law. Observations from the United Kingdom and the Netherlands, „European Business Law Review", vol. 27 no. 1, pp. 1-23.

European Commission (EC) (2003), Company law and corporate governance: Commission presents Action Plan, http://europa.eu/rapid/press-release_IP-03-716_en.htm?locale=en [17.02.2018].

EC (2009), Study on monitoring and enforcement practices in corporate governance in the member states, $\quad 23 \quad$ September 2009 , http://ec.europa.eu/internal_market/company/docs/ecgforum/studies/comply-or-explain-090923_en.pdf [17.02.2018].

EC (2010), EUCO 13/10. Conclusions of the European Council of 17 June 2010, http://www.consilium.europa.eu/ueDocs/cms_Data/docs/pressData/en/ec/115346.pdf [17.02.2018].

EC (2011), Green Paper. The EU corporate governance framework, $\operatorname{COM}(2011) 164$ final, http://ec.europa.eu/internal_market/company/docs/modern/com2011-164_en.pdf [17.02.2018].

EC (2013a), Prudential requirements, https://ec.europa.eu/info/business-economy-euro/banking-andfinance/financial-supervision-and-risk-management/managing-risks-banks-and-financialinstitutions/prudential-requirements_en [17.02.2018].

EC (2013b), CRD IV/CRR - Frequently Asked Questions, europa.eu/rapid/press-release_MEMO-13272_en.htm [17.02.2018].

EC (2016), Environment. Sustainable development, http://ec.europa.eu/environment/sustainabledevelopment/index_en.htm [17.02.2018].

Edwards V. (1999), EC company law, Oxford University Press, New York.

Eurostat (2016), Sustainable development in the European Union. A statistical glance from the viewpoint of the UN sustainable development goals, http://ec.europa.eu/eurostat/documents/3217494/7745644/KS-02-16-996-EN-N.pdf [17.02.2018].

G20/OECD (2015), Principles of corporate governance, http://www.oecd.org/daf/ca/principlescorporate-governance.htm [17.02.2018]. 


\section{EU RULES ON CORPORATE GOVERNANCE AS MEANS TO PROMOTE ...}

Krugman P.R., (2012), Sortez-nous de cette crise... maintenant! (End this depression now!), Flammarion, Paris.

Majerbi B., Rachdi H., (2014), Systemic banking crises, financial liberalisation and governance, „Multinational Finance Journal”, vol. 18 no. 3/4, pp. 281-336.

Murphy D.T. (1985), The amendment proposal for a Fifth Company Law Directive - nihil novum, „Houston Journal of International Law”, vol. 7 no. 215, pp. 215-235, https://scholarship.richmond.edu/cgi/viewcontent.cgi?referer=https://www.google.pl/\&httpsredir=1\&ar ticle $=1354 \&$ context=law-faculty-publications [17.02.2018].

OECD (2004), Principles of Corporate Governance, http://www.oecd.org/dataoecd/32/18/31557724.pdf [17.02.2018].

Picketty T. (2013), Le capital au XXIe siècle (Capital in the twenty-first century), Seuil, Paris.

Söderström R. (2015), Regulating banks in Europe, „European Company Law”, vol. 12 no. 2, pp. 115119.

Tuori K., Tuori K. (2014), The Eurozone crisis. A constitutional analysis, Cambridge University Press, New York.

Vogel D.H. (2007), Corporate governance. Überlegungen versus Unternehmertum (Considerations versus entrepreneurship), in: Werte. Was die Gesellschaft zusammenhält (Values. What holds the society together), ed. Mohn L., Mohn B., Weidenfeld W., Meier J., Bertelsmann Stiftung Verlag, Gütersloh, pp. 217-233.

Vossestein G-J. (2010), Modernisation of European company law and corporate governance. Some considerations on its legal limits, Wolters Kluwer, The Hague.

Wouters J. (2000), European company law: quo vadis?, „Common Market Law Review”, vol. 37, pp. 257-307.

\section{Legal acts}

The Council of the European Communities (CEC) (1968), First Council Directive 68/151/EEC of 9 March 1968 on co-ordination of safeguards which, for the protection of the interests of members and others, are required by Member States of companies within the meaning of the second paragraph of Article 58 of the Treaty, with a view to making such safeguards equivalent throughout the Community OJ L 65, 14.3.1968, p. 8-12; English special edition: Series I Volume 1968(I), pp. 41-45, http://eurlex.europa.eu/legal-content/EN/TXT/?uri=CELEX\%3A31968L0151 [17.02.2018].

CEC (1973), Council Directive 73/183/EEC of 28 June 1973 on the abolition of restrictions on freedom of establishment and freedom to provide services in respect of self- employed activities of banks and other financial institutions OJ L 194, 16.7.1973, http://eur-lex.europa.eu/legalcontent/EN/TXT/?uri=CELEX\%3A31973L0183 [17.02.2018]. 
CEC (1978), Fourth Council Directive 78/660/EEC of 25 July 1978 based on Article 54 (3) (g) of the Treaty on the annual accounts of certain types of companies, http://eur-lex.europa.eu/legalcontent/EN/TXT/?uri=OJ:L:1978:222:TOC [17.02.2018].

CEC (1989a), Second Council Directive 89/646/EEC of 15 December 1989 on the coordination of laws, regulations and administrative provisions relating to the taking up and pursuit of the business of credit institutions and amending Directive 77/780/EEC, OJ L 386, 30.12.1989, http://eurlex.europa.eu/eli/dir/1989/646/oj [17.02.2018].

CEC (1989b), Twelfth Council Company Law Directive 89/667/EEC of 21 December 1989 on singlemember private limited-liability companies, OJ L 395, 30.12.1989, http://eur-lex.europa.eu/legalcontent/EN/TXT/?uri=celex\%3A31989L0667 [17.02.2018].

Council of European Union (CEU) (1977), First Council Directive 77/780/EEC of 12 December 1977 on the coordination of the laws, regulations and administrative provisions relating to the taking up and pursuit of the business of credit institutions, OJ L 322, 17.12.1977, http://eur-lex.europa.eu/legalcontent/EN/ALL/?uri=CELEX\%3A31977L0780 [17.02.2018].

CEU (1982), Sixth Council Directive 82/891/EEC of 17 December 1982 based on Article 54 (3) (g) of the Treaty, concerning the division of public limited liability companies, OJ L 378, 31.12.1982, http://eur-lex.europa.eu/legal-content/EN/TXT/?uri=LEGISSUM\%3Al26008 [17.02.2018].

CEU (1985), Council Regulation (EEC) No 2137/85 of 25 July 1985 on the European Economic Interest Grouping (EEIG), OJ L 199, 31.7.1985, pp. 1-9, http://eur-lex.europa.eu/legalcontent/EN/ALL/?uri=celex\%3A31985R2137 [18.02.2018].

CEU (1989), Eleventh Council Directive 89/666/EEC of 21 December 1989 concerning disclosure requirements in respect of branches opened in a Member State by certain types of company governed by the law of another State, http://eur-lex.europa.eu/legalcontent/EN/ALL/?uri=CELEX\%3A31989L0666 [17.02.2018].

CEU (1998), Declaration by the Council (ECOFIN) and the Ministers meeting in that Council issued on 1 May 1998, OJ L 139/28, https://publications.europa.eu/en/publication-detail//publication/28641a25-0522-4332-b7cf-d27102c89354/language-en [17.02.2018].

CEU (2013), Council Regulation (EU) No 1024/2013 of 15 October 2013, conferring specific tasks on the European Central Bank concerning policies relating to the prudential supervision of credit $\begin{array}{llrrr}\text { institutions, } & \text { OJ } & \text { L } & 287, & \text { pp. }\end{array}$ http://www.europarl.europa.eu/document/activities/cont/201311/20131104ATT73792/20131104ATT7 3792EN.pdf [17.02.2018].

CEU (2016), Council Directive (EU) 2016/1164 of 12 July 2016 laying down rules against tax avoidance practices that directly affect the functioning of the internal market, OJ L 193, 19.7.2016, pp. 1-14, http://eur-lex.europa.eu/legal-content/EN/TXT/?uri=uriserv:OJ.L_.2016.193.01.0001.01.ENG [17.02.2018].

European Court of Justice (ECJ) (1999), Judgment of the Court of 9 March 1999. Centros Ltd v Erhvervs- og Selskabsstyrelsen, http://eur-lex.europa.eu/legalcontent/EN/ALL/?uri=CELEX\%3A61997CJ0212 [17.02.2018]. 


\section{EU RULES ON CORPORATE GOVERNANCE AS MEANS TO PROMOTE ...}

European Union (EU) (2000), Directive 2000/12/EC of the European Parliament and of the Council of 20 March 2000 relating to the taking up and pursuit of the business of credit institutions, OJ L 126, 26.5.2000, http://eurlex.europa.eu/LexUriServ/LexUriServ.do?uri=OJ:L:2000:126:0001:0059:EN:PDF [17.02.2018].

EU (2003), Communication from the Commission to the Council and the European Parliament Modernising Company Law and Enhancing Corporate Governance in the European Union - A Plan to Move Forward, http://eur-lex.europa.eu/legal-content/PL/TXT/?uri=celex\%3A52003DC0284 [17.02.2018].

EU (2004), Directive 2004/25/EC of the European Parliament and of the Council of 21 April 2004 on takeover bids, OJ L 142, 30.4.2004, http://eur-lex.europa.eu/legalcontent/EN/TXT/?uri=celex\%3A32004L0025 [17.02.2018].

EU (2005), Directive 2005/56/EC of the European Parliament and of the Council of 26 October 2005 on cross-border mergers of limited liability companies (Text with EEA relevance), http://eurlex.europa.eu/legal-content/EN/TXT/?uri=celex:32005L0056 [17.02.2018].

EU (2006a), Directive 2006/43/EC of the European Parliament and of the Council of 17 May 2006 on statutory audits of annual accounts and consolidated accounts, amending Council Directives 78/660/EEC and 83/349/EEC and repealing Council Directive 84/253/EEC (Text with EEA relevance), http://eur-lex.europa.eu/legal-content/EN/TXT/?uri=CELEX\%3A32006L0043 [17.02.2018].

EU (2006b), Directive 2006/46/EC of the European Parliament and of the Council of 14 June 2006 amending Council Directives 78/660/EEC on the annual accounts of certain types of companies, 83/349/EEC on consolidated accounts, 86/635/EEC on the annual accounts and consolidated accounts of banks and other financial institutions and 91/674/EEC on the annual accounts and consolidated accounts of insurance undertakings (Text with EEA relevance), http://eur-lex.europa.eu/legalcontent/FRN/TXT/?uri=celex:32006L0046 [17.02.2018].

EU (2007), Directive 2007/36/EC of the European Parliament and of the Council of 11 July 2007 on the exercise of certain rights of shareholders in listed companies, http://eur-lex.europa.eu/legalcontent/EN/TXT/?uri=celex\%3A32007L0036 [17.02.2018].

EU (2009), Directive 2009/49/EC of the European Parliament and of the Council of 18 June 2009 amending Council Directives 78/660/EEC and 83/349/EEC as regards certain disclosure requirements for medium-sized companies and the obligation to draw up consolidated accounts (Text with EEA relevance), http://eur-lex.europa.eu/legal-content/EN/ALL/?uri=celex\%3A32009L0049 [17.02.2018].

EU (2010), Directive 2010/76/EU of the European Parliament and of the Council of 24 November 2010 amending Directives 2006/48/EC and 2006/49/EC as regards capital requirements for the trading book and for resecuritisations, and the supervisory review of remuneration policies, OJ L 329, 14.12.2010, pp. 3-35, http://eur-lex.europa.eu/legal-content/EN/TXT/?uri=CELEX\%3A32010L0076 [17.02.2018].

EU (2012), Communication from the Commission to the European Parliament, the Council, the European Economic and Social Committee and the Committee of Regions. Action Plan: European company law and corporate governance - a modern legal framework for more engaged shareholders and sustainable companies, $\operatorname{COM}(2012) 740$ final, http://eur-lex.europa.eu/legalcontent/EN/ALL/?uri=celex:52012DC0740 [17.02.2018]. 
EU (2013a), Directive 2013/36/EU of the European Parliament and of the Council of 26 June 2013 on access to the activity of credit institutions and the prudential supervision of credit institutions and investment firms, $\quad$ OJ $\quad \mathrm{L} \quad 176, \quad \mathrm{http} / / /$ eur-lex.europa.eu/legalcontent/EN/TXT/?uri=celex\%3A32013L0036 [17.02.2018].

EU (2013b), Regulation No 575/2013 of the European Parliament and of the Council of 26 June 2013 on prudential requirements for credit institutions and investment firms and amending Regulation (EU) No 648/2012, OJ L 176, 27.6.2013, Pp. 1-337, http://eur-lex.europa.eu/legalcontent/en/TXT/?uri=celex\%3A32013R0575 [17.02.2018].

EU (2013c), Regulation No 1024/2013 of the European Parliament and the Council of 22 October 2013 amending Regulation (EU) No 1093/2010 establishing a European Supervisory Authority (European Banking Authority) as regards the conferral of specific tasks on the European Central Bank pursuant to Council Regulation (EU) No 1024/2013, OJ L287, pp. 5-14, http://eur-lex.europa.eu/legalcontent/EN/TXT/?uri=celex\%3A32013R1022 [17.02.2018].

EU (2014a), Commission Delegated Regulation No 527/2014 of 12 March 2014 supplementing Directive (EU) No 2013/36/EU of the European Parliament and of the Council with regard to regulatory technical standards specifying the classes of instruments that adequately reflect the credit quality of an institution as a going concern and are appropriate to be used for the purposes of variable remuneration, OJ L 148, 20.5.2014, pp. 21-28.

EU (2014b), Directive 2014/59/EU of the European Parliament and of the Council of 15 May 2014 establishing a framework for the recovery and resolution of credit institutions and investment firms and amending Council Directive 82/891/EEC, and Directives 2001/24/EC, 2002/47/EC, 2004/25/EC, 2005/56/EC, 2007/36/EC, 2011/35/EU, 2012/30/EU and 2013/36/EU, and Regulations (EU) No 1093/2010 and (EU) No 648/2012, OJ L 173, 12.6.2014, pp. 190-348, http://eur-lex.europa.eu/legalcontent/EN/TXT/?uri=celex\%3A32014L0059 [17.02.2018].

EU (2014c), Regulation No 806/2014 of the European Parliament and of the Council of 15 July 2014 establishing uniform rules and a uniform procedure for the resolution of credit institutions and certain investment firms in the framework of a Single Resolution Mechanism and a Single Resolution Fund and amending Regulation (EU) No 1093/2010, OJ L 225, 30.7.2014, pp. 1-90, http://eurlex.europa.eu/legal-content/EN/TXT/?uri=celex\%3A32014R0806 [17.02.2018].

EU (2014d), Proposal for a Directive of the European Parliament and of the Council amending Directive 2007/36/EC as regards the encouragement of long-term shareholder engagement and Directive 2013/34/EU as regards certain elements of corporate governance statement, COM(2014) 213 final, http://eur-lex.europa.eu/legal-content/EN/TXT/?uri=COM\%3A2014\%3A213\%3AFIN [17.02.2018].

EU (2017), Directive 2017/828 of the European Parliament and of the Council of 17 May 2017 amending Directive 2007/36/EC as regards the encouragement of long-term shareholder engagement, OJ L 132, 20.5.2017, pp. 1-25, http://eur-lex.europa.eu/legalcontent/EN/TXT/?uri=CELEX:32017L0828 [17.02.2018]. 